\title{
ks. Lucjan Świto, Alienacja majątku kościelnego w diecezjach rzymsko- katolickich w Polsce, Biblioteka Wydziału Teologii Uniwersytetu Warmińsko- -Mazurskiego w Olsztynie, Olsztyn 2010, ss. 273
}

Niniejsza monografia podejmuje ważne i aktualne zagadnienie, mieszczące się w nurcie problematyki, której ojcowie Soboru Watykańskiego II poświęcili sporo uwagi. Jednym z wniosków płynących z pryncypiów katolickiej nauki społecznej - trzech zasad: autonomii i niezależności Kościoła i państwa, współdziałania Kościoła i państwa w osiąganiu wspólnego dobra osoby ludzkiej oraz poszanowania wolności religijnej w wymiarze indywidualnym i wspólnotowym - jest dyrektywa „wolności działania, jakiej wymaga troska o zbawienie ludzi” (dekl. Dignitatis humanae, nr 13). Podmiot kościelny, aby mógł działać - pisał śp. prof. Remigiusz Sobański w znanym studium Baza finansowa Kościołów w perspektywie zintegrowanej Europy („Prawo Kanoniczne” 1996, nr 3-4, s. 9) - potrzebuje, jak każdy inny podmiot, wolności podejmowania decyzji i jednocześnie środków niezbędnych do ich realizacji. Sedno tak postawionego problemu jest zogniskowane wokół dwóch przesłanek. Po pierwsze, skoro wypełnianie rzeczonego celu podstawowego (salus animarum) nie byłoby możliwe bez tzw. bazy materialnej, „Kościół posługuje się rzeczami doczesnymi, na ile wymaga tego jego posłannictwo" (konst. Gaudium et spes, nr 76). Po wtóre, z uwagi na wielorakie zaangażowanie Kościoła w sferze etyczno-moralnej, społecznej i kulturowej, nie do przecenienia są „uniwersalne” korzyści płynące z realizacji jego misji. Owszem, odnoszą je przede wszystkim wierni i wspólnoty kościelne, lecz w niemałym stopniu także całe społeczeństwo (działalność charytatywna i opiekuńcza, szkolnictwo, ochrona zabytków itp.). I stąd oczywisty postulat w budowaniu relacji państwa do Kościoła katolickiego (oraz innych Kościołów i związków wyznaniowych): aktywnej promocji wolności religijnej oraz doceniania miejsca i roli podmiotów kościelnych w sferze publicznej; w konkretnym zaś odniesieniu do wspomnianej bazy materialnej Kościoła - postulat pełnego uznania deklaracji normatywnej, zapisanej w Kodeksie prawa kanonicznego z 1983 roku: „Kościół katolicki na podstawie prawa wrodzonego, niezależnie od władzy świeckiej, może dobra doczesne nabywać, posiadać, zarządzać i alienować, dla osiągnięcia właściwych sobie celów” (kan. $1254 \$ 1$ ).

W taki krąg problemowy wpisuje się ks. L. Świto swą monografią, gdy już na wstępie zakreśla główną kwestię badawczą pytaniem: „w jakim zakresie normy wewnętrzne obowią- 
zujące w strukturze organizacyjnej Kościoła katolickiego w Polsce mogą wpływać na ważność czynności prawnych związanych z zarządzaniem mieniem kościelnym na gruncie prawa polskiego?” (s. 5). Prezentację zagadnienia alienacji majątku kościelnego jako tematu rozprawy Autor poprzedza dwoma istotnymi uwagami: pierwsza (poczyniona chyba zbyt lakonicznie), że sprawy majątkowe Kościoła katolickiego należą do kategorii tzw. spraw mieszanych, czyli spraw, które leżą w gestii zarówno władzy kościelnej, jak i władzy państwowej, i druga, nie mniej ważna - zwłaszcza wobec ciągle rosnącego udziału Kościoła w obrocie gospodarczym - o znaczeniu faktora „czasu”: należy mieć na względzie zmieniające się dynamicznie uwarunkowania ekonomiczno-społeczne. W dalszej części Wstępu Autor wskazuje (znowu bardzo oszczędnie w słowach) na trzy płaszczyzny analiz, obejmujące 1) optykę kanonicznoprawną zagadnienia, 2) optykę prawa państwowego oraz 3) optykę wzajemnych odniesień przedmiotowych uregulowań prawnych w obu systemach. Już w tym miejscu łatwo się zorientować, że książka ks. L. Świty stanowi oryginalne, kompleksowe opracowanie zagadnienia alienacji dóbr doczesnych w polskich realiach systemowo-prawnych. Co przy tym wymaga zaznaczenia, ów ważny projekt badawczy usuwa lukę, której dotąd nie zdołały wypełnić ani komentarze do norm prawa kodeksowego (kan. 1273-1298 KPK), ani „okazyjne” podejmowanie niniejszego tematu przez autorów polskich: kanonistów i cywilistów.

Rozpoznana we Wstępie złożoność problematyki i „rozległość przedmiotowej materii” podpowiadały Autorowi przyjęcie takich, a nie innych ram treściowych i metodologicznych. Toteż ambitny cel badawczy, zdefiniowany ogólnie jako „próba całościowej analizy” zagadnienia „alienacji majątku kościelnego” (pierwszy człon tytułu) ... w Polsce (s. 6) - został poddany zabiegowi dodatkowego sprofilowania. W związku z tym drugi człon tytułu monografii przyjął ostatecznie kształt: „...w diecezjach rzymskokatolickich w Polsce”. Poza zasadniczymi ramami analiz musiały - w ocenie Autora - pozostać instytuty życia konsekrowanego i stowarzyszenia życia apostolskiego. Dobrze, że zostajemy o tym poinformowani we Wstępie, choć wypada dodać, że kilkakrotne świadome przekraczanie owych ram (zob. tytuły w rozdziale I: pkt 3.7 i 5.3.3 oraz w rozdziale II: pkt 3.4) każe pytać, czy podjęta decyzja została do końca przemyślana. Nie znajdziemy natomiast takiej samej wstępnej informacji o zawężeniu kręgu „podmiotów kościelnych mogących być stroną alienacji oraz zarządców uprawnionych do ich reprezentowania” (s. 7). Dopiero z jednozdaniowej introdukcji rozpoczynającej pkt. 3 rozdziału II czytelnik dowiaduje się, że mnogość kościelnych osób prawnych, a także ramy zakreślone tematem uzasadniają, przedstawienie „reprezentacji [raczej grupy; użycie słowa „reprezentacja” jest tu niefortunne, skoro później będzie mowa o reprezentacji prawnej - A. P.] najbardziej typowych kościelnych osób prawnych” (s. 65). Pytanie o ostre kryterium owej typowości pozostaje bez odpowiedzi, bo trudno uznać za takową frazę Wstępu: „swoiste kompendium wiedzy”, w odniesieniu do wymienionych podmiotów kościelnych. 
Książkę cechuje stosunkowo częste, bezpośrednie sięganie do źródeł prawa: kanonicznego (powszechnego i partykularnego) i polskiego. W pierwszym przypadku krąg powoływanych komentatorów kodeksów z 1917 i 1983 roku - z „co rusz” pojawiającymi się nazwiskami: F. Bączkowicz, T. Pawluk i W. Wójcik (obok wymienionych, częściej cytowany jest jeszcze M. Sitarz; wszyscy oni są prezentowani we Wstępie) - można było szerzej otworzyć na cenionych w świecie kanonistów, znanych autorów komentarzy zagranicznych. Aby nie być gołosłownym - Literatura obejmuje wcale pokaźną grupę włoskich kanonistów, tylko że liczba cytowań ich pozycji na stronicach książki jest ograniczona. Ponadto dziwi niewykorzystanie dwóch wielkich komentarzy: „pampeluńskiego” (Comentario exegético al Código de Derecho canónico, ed. Á. Marzoa, J. Miras, R. Rodríguez-Ocaña, Pamplona 200233) i niemieckiego (Münsterischer Kommentar zum „Codex Iuris Canonici”, hrsg. K. Lüdicke [dalej: MK], Essen 1984-), choć w przypadku tego ostatniego komentarza ks. L. Świto uczynił jeden wyjątek (cytowany jest K. Lüdicke - s. 146, przyp. 10). Jeśli nie liczyć drobiazgowego prezentowania opinii glosatorów do orzeczeń Sądu Najwyższego (w rozdziale IV), Autor-kanonista nieczęsto korzysta też z komentarzy do kodeksów prawa polskiego (cywilnego, karnego) - co owszem, świadczy o biegłości i swobodnym poruszaniu się w obszarze prawa państwowego (tu Autor zasługuje na uznanie), może jednak rodzić pytania o stopień pogłębienia naukowej refleksji. I jeszcze uwaga generalna: o ile umiarkowanie szeroką kwerendą objęta została literatura polska, o tyle w stopniu zdecydowanie mniejszym zostały uwzględnione pozycje obcojęzyczne (głównie włoskie). Owa asymetria, efekt „programowo” minimalistycznego podejścia Autora do literatury światowej, nie daje się łatwo usprawiedliwić zdaniem ze Wstępu: „Z uwagi na specyfikę obszaru badawczego zakreślonego tematem, a zwłaszcza z uwagi na fakt, iż odnosi się on do rozwiązań prawnych istniejących w prawodawstwie polskim, zagadnienie to nie było przedmiotem opracowań również w literaturze obcojęzycznej” (s. 6).

Książka ks. L. Świty składa się ze Wstępu (s. 5-8), pięciu rozdziałów (s. 9-228), Zakończenia (s. 229-234), Wykazu skrótów (s. 235), Bibliografii (s. 237-256), Spisu treści w języku angielskim (s. 257-261), włoskim (263-267) i w języku polskim (s. 269-273). Zauważalnym brakiem jest niezamieszczenie streszczenia w języku obcym, co powinno być standardem w tego typu pracach naukowych. Struktura całości została przez Autora zwięźle przedstawiona i uzasadniona we Wstępie, zredagowanym według przyjętych zasad. Z jednej strony można uznać, że wybór zwartej formy wypowiedzi udobitnił przejrzystość i dobre zaplanowanie poszczególnych segmentów konstrukcji rozprawy. Z drugiej strony jednak wybór krótkiej formy słowa wstępnego sprawił, że nie starczyło miejsca, by starannie zapoznać czytelnika z metodami badawczymi. Ostatnie zdanie Wstępu komunikuje: „W pracy zastosowano metodę dogmatyczno-prawną oraz historyczno-prawną" (s. 8). Jak do tej lakonicznej wzmianki mają się zapowiedzi prezentacji badań ankietowych, przeprowadzonych w diecezjach polskich, czy też porównawczego zestawienia polskich i włoskich uregulowań w przed- 
miotowej materii (zob. s. 7), czy wreszcie podejmowane w rozprawie próby naukowego poszukiwania sensu ustaw: kościelnych i państwowych (zob. s. 106, 169, 170-171, 188-189, 192-193, 233-234) - tego się w tym miejscu nie dowiadujemy.

Merytoryczny przekaz narracji zyskałby na wyrazistości, gdyby Autor zechciał „na bieżąco” zapoznawać czytelnika ze szczegółowym projektem i rezultatami kolejnych etapów badawczych. Może dziwić zwłaszcza brak kończącego każdy rozdział podsumowania, a to w sytuacji, gdy w Zakończeniu znalazło się - jedynie! - miejsce, by przedstawić owoce badań rozdziałów III i IV (oczywiście ważnych, bo bezpośrednio nawiązujących do tytułowej „alienacji”).

Do czterech rozdziałów: dwóch wprowadzających (uzasadnionych - jak rzeczowo objaśniono - „organicznym połączeniem [problematyki alienacji] z problematyką majątku kościelnego i osobowości prawnej podmiotów kościelnych” - s. 6) i dwóch centralnych (z łatwo rozpoznawalnym głównym nurtem dyskursu), Autor dołącza jeszcze jedną jednostkę tematyczną - nader interesującą, o czym świadczy już sama autorska zapowiedź: „Rozdział piąty jest [...] swoistym znakiem czasów i ujmuje alienację mienia kościelnego w kontekście funduszy unijnych” (s. 7). Szkoda tylko, że rozdział ten objętością (15 stron) wyraźnie odbiega od poprzednich i wprowadza jako efekt finalny - z pewnością niezamierzoną przez Autora - asymetrię kompozycji. Ponadto w oczy rzuca się redakcyjny „kłopot” z zapisanym w tytule monografii określeniem miejsca: „w Polsce”. Uważam, że podjęta została niewłaściwa decyzja, by określenie to powtarzać w poszczególnych rozdziałach lub/oraz podrozdziałach. Należało tak zaplanować intytulację, by nie prowokować pytań typu: dlaczego w jednej jednostce to określenie występuje, a w innej nie (np. powinno ono się znaleźć w tytule pkt. 3 rozdziału IV, skoro jest w tytułach pkt. 2 i 4). Ponadto, treść II rozdziału lepiej opisywałby „prosty” tytuł: „Osobowość prawna podmiotów kościelnych i ich reprezentacja”. Przedstawione krytyczne uwagi nie zmieniają pozytywnej opinii o strukturze rozprawy: układ formalny pracy należy uznać za poprawny i przekonująco uzasadniony.

Sygnalizowane mankamenty są marginalne w zestawieniu z merytorycznymi walorami rozprawy. Podstawowym osiągnięciem ks. L. Świty jest rzetelne rozpoznanie głównej kwestii badawczej. Odpowiedź na kluczowe pytanie postawione we Wstępie - w oparciu o szeroką i bynajmniej nie powierzchowną analizę źródeł - została udzielona przekonująco. Cywilnoprawna skuteczność czynności alienacyjnych dokonywanych przez kościelne osoby prawne nie może być oceniana w perspektywie jej skuteczności kanonicznoprawnej. Wszak „skuteczność unormowań regulacji kościelnych w obrębie świeckiego porządku prawnego - jak kompetentnie wywodzi Autor - możliwa jest tylko wtedy, gdy istnieje ku temu podstawa prawna w przepisach prawa powszechnie obowiązującego" (s. 187). Cenne ustalenia dotyczące konieczności podjęcia działań legislacyjnych (ze wskazywaniem pożądanych kierunków aktywności ustawodawcy kościelnego czy państwowego - co, trochę „na wyrost”, Autor nazywa swymi postulatami 
de lege ferenda) dotyczą trzech zasadniczych obszarów: 1) W celu zapewnienia bezpieczeństwa obrotu majątkiem kościelnym w naszym kraju Konferencja Episkopatu Polski nie powinna dalej zwlekać z wypełnieniem dyspozycji kodeksowej zapisanej w kan. 1277: „Biskup diecezjalny przed podjęciem aktów dotyczących zarządu o większym znaczeniu ze względu na materialny stan diecezji, powinien wysłuchać zdania Rady do spraw ekonomicznych i kolegium konsultorów. Winien zaś uzyskać zgodę tej Rady oraz kolegium konsultorów, oprócz wypadków szczegółowo wyliczonych w prawie powszechnym oraz w prawie fundacyjnym, również dla podjęcia aktów nadzwyczajnego zarządzania. Konferencja Episkopatu zaś powinna określić, które akty należy zaliczyć do nadzwyczajnego zarządzania”; 2) Z uwagi na okoliczność, że zgoda tzw. osoby zainteresowanej jest warunkiem sine qua non ważności umów alienacyjnych, brak ustawowych kryteriów określających wymienioną osobę i jej prawdziwy status (kryteriów relewantnych także w prawie cywilnym) jawi się jako dolegliwa luka prawna; jej wypełnienie stanowi nader aktualne wyzwanie stojące przed prawodawcą kościelnym; 3) Brak precyzyjnych zapisów normujących zakres reprezentacji kościelnych osób prawnych - tak, by wyeliminować niepotrzebne problemy interpretacyjne w doktrynie prawnej i orzecznictwie (z pożytkiem dla zarządców majątku kościelnego oraz ich świeckich kontrahentów) - także i w tym przypadku domaga się powzięcia odpowiedniej inicjatywy legislacyjnej. Już sama istotność wymienionych wniosków pozwala widzieć w Autorze dociekliwego badacza, odważnie penetrującego złożone i trudne kwestie związane z tytułem monografii - równie kompetentnie w płaszczyźnie prawa kanonicznego, jak i prawa polskiego. Operując dobrym warsztatem naukowym, Autor nie stroni od otwartych polemik (np. trzykrotnie nie zgadza się w niebłahych kwestiach ze znawcą przedmiotowej problematyki ks. prof. M. Sitarzem - s. 70, 91, 111-112, raz ze śp. ks. prof. R. Sobańskim - s. 135). Zwłaszcza w trzech ostatnich rozdziałach czytelnik „styka się” z solidnością prowadzonych analiz oraz rzeczowością sądów i ocen. W tym kontekście pewną wątpliwość, czy Autor zachował równowagę między korzystaniem z dorobku innych a „wkładem” własnym, nastręcza lektura I rozdziału. Ta część rozprawy jest wyraźnie inspirowana treściami książki D. Walencika, Rewindykacja nieruchomości Kościoła katolickiego w postępowaniu przed Komisją Majątkowa, Lublin 2009 (szczególnie rozdziałem 3). Niektóre zapożyczenia, ogólnie sygnalizowane - bo raz po raz pojawiają się odesłania do wymienionej pozycji - sięgają tak dalece, że bliźniaczo podobna jest redakcja kilku kolejnych przypisów w obu monografiach (przypisy na s. 25 - są odbiciem tych na s. 56-57 w pracy przywołanego autora); innym razem rzecz dotyczy pojedynczych przypisów, w miejscu, gdzie w ogóle nie ma odesłania do książki D. Walencika (przypisy 147, 151, 153 na s. 34 i 35-36 odpowiadają przypisom 91, 95, 98 na s. 151 i 152 tej książki; a przypisy 171, 172, 174 na s. 39 odpowiednio przypisom 161, 162 i 164,165 na s. 164-165). Rodzi się pytanie, czy nie należało we Wstępie objaśnić celowości szerokiego wykorzystania owoców badań wymienionego prawnika? 
Rozdział I książki (s. 9-52), rozpoczęty określeniem pojęcia kościelnych dóbr doczesnych, ma w zamyśle Autora - przez włączenie optyki historycznej (obok „dzisiejszej” perspektywy) - wprowadzić czytelnika w meandry „trudnego zagadnienia sukcesji majątkowej Kościoła katolickiego”. Od początku ks. L. Świto jest świadomy znaczenia trafnie dobranej metodologii prowadzonego dyskursu. Widać to w przyjętej systematyce, która po zwięzłym przedstawieniu genezy i dziejów systemu beneficjalnego oraz omówieniu rodzajów dóbr doczesnych, każe oświetlić - konsekwentnie w ujęciu diachronicznym (stąd powtórzenia niektórych jednostek tematycznych w punktach 3 i 5.3 tego rozdziału) - zagadnienia: kościelnych dóbr doczesnych w II Rzeczpospolitej i nacjonalizacji tegoż mienia po 1945 roku, by finalnie skupić uwagę na problematyce rewindykacji utraconej własności Kościoła katolickiego w wolnej Polsce (po roku 1989). Podstawowy akt normatywny regulujący sytuację prawną tego Kościoła - Ustawa o stosunku Państwa do Kościoła katolickiego w Polskiej Rzeczpospolitej Ludowej z 17 maja 1989 roku - umożliwiła dochodzenie zwrotu odebranego majątku przez władze PRL. Artykuł 60. ustawy wprowadza tryb „uwłaszczenia” - pierwszy administracyjny tryb rewindykacji - zgodnie z którym decyzją wojewody nieruchomości lub ich części, pozostające w dniu wejścia w życie rzeczonej ustawy we władaniu kościelnych osób prawnych, stają się z mocy prawa ich własnością. Zastosowanie tego trybu było możliwe wobec mienia pounickiego, tzw. dóbr martwej ręki, mienia fundacji, mienia przejętego przez austriackie władze zaborcze oraz obiektów sakralnych i cmentarzy. Inny tryb administracyjny rewindykacji majątku kościelnego umożliwiła nowelizacja z 11 października 1991 roku omawianej ustawy (już ze zmienioną nazwą: Ustawa... w Rzeczpospolitej Polskiej). Jej art. 70a stanowi, że położone na Ziemiach Odzyskanych diecezje, seminaria duchowne i domy zakonne (m.in. te, które prowadziły działalność oświatową lub charytatywno-opiekuńcza) mogą - w drodze administracyjnej decyzji wojewody - uzyskać określone rekompensaty za znacjonalizowane nieruchomości rolne w postaci nieodpłatnego przekazania na własność gruntów z zasobów Państwowego Funduszu Ziemi. Wreszcie tryb tzw. postępowania regulacyjnego (o charakterze arbitrażowo-jurysdykcyjnym) zakładał - zgodnie z art. 61-64 ustawy o stosunku Państwa do Kościoła katolickiego w Rzeczpospolitej Polskiej - zwrócenie się kościelnych osób prawnych do powołanej 28 kwietnia 1990 roku Komisji Majątkowej o zwrot tych upaństwowionych nieruchomości, które z wejściem w życie ustawy nie znajdowały się we „władaniu” Kościoła. Autor szczegółowo egzemplifikuje zastosowanie owego trybu do: mienia pounickiego, dóbr martwej ręki i lasów, mienia zakonów bezhabitowych i stowarzyszeń kościelnych, mienia fundacji kościelnych, nieruchomości przejętych przez egzekucję zaległości podatkowych, nieruchomości wywłaszczonych, mienia warszawskiego, mienia przejętego bez podstawy prawnej, nieruchomości, w których sprawowany był kult religijny oraz nieruchomości, których stan prawny nie był ustalony. Tu warto dodać, że zniesienie Komisji Majątkowej 
1 marca 2011 roku zakończyło zwrot mienia kościelnego w trybie postępowania regulacyjnego. Nierozstrzygnięte przez Komisję wnioski będą rozstrzygane na drodze postępowania sądowego na wniosek uczestników postępowania regulacyjnego.

W rozdziale II (s. 53-88) ks. L. Świto stawia sobie za cel systematyczne ujęcie kościelnych osób prawnych z wyszczególnieniem organów uprawnionych do ich reprezentowania. Naturalnie ramy wyznaczone tematem rozprawy podpowiadały Autorowi skoncentrowanie uwagi na podmiotach podlegających władzy biskupa diecezjalnego. Uzyskujemy przeto miarodajny syntetyczny zarys problematyki prawnokanonicznej regulowanej przepisami księgi I i II KPK - anonsowanej tytułami głównych podrozdziałów: pojęcie kościelnej osoby prawnej oraz wybrane kościelne osoby prawne. Te dwa podrozdziały (oznaczone jako pierwszy i trzeci) dzieli podrozdział (drugi) poświęcony osobowości cywilnoprawnej podmiotów kościelnych. Zabieg ten, niewyjaśniony we Wstępie, miał zapewne gwarantować kompleksowość (i kompletność) opisu umocowania tych ostatnich w obu wymienionych porządkach prawnych. Tyle, że wyraźne dysproporcje ilościowe między jedną i drugą perspektywą - ze zdecydowaną przewagą optyki kanonicznoprawnej (o czym świadczy zaledwie trzystronicowy podrozdział drugi, a w trzecim podrozdziale - nierzadko jednozdaniowa tylko wzmianka o cywilnoprawnym statusie i reprezentacji wybranych podmiotów kościelnych) - sprawiły, że zamysł ten nie do końca się powiódł. Wzmiankowanej tematyce ostatniego podrozdziału Autor, co zrozumiałe, poświęca najwięcej miejsca, omawiając - wedle właściwie przyjętej kolejności: diecezje, archidiecezje i metropolie, parafie, kapituły kanonickie, instytuty życia konsekrowanego i stowarzyszenia życia apostolskiego, stowarzyszenia wiernych (z wyszczególnieniem organizacji katolickich i organizacji kościelnych), seminaria duchowne i kościelne szkoły wyższe, fundacje kościelne i w końcu instytucje sygnowane tytułem „inne osoby kościelne”, jak: Konferencja Episkopatu Polski, Caritas Polska oraz Papieskie Dzieła Misyjne. W tym segmencie monografii, na pewno interesującym, zabrakło trochę metodologicznej konsekwencji. Można bowiem pytać, dlaczego jedne jednostki tematyczne zawierają rys historyczny (takiż, i to dość obszerny, mają np. kapituły kanonickie), a inne nie (np. instytuty życia konsekrowanego i stowarzyszenia życia apostolskiego czy stowarzyszenia wiernych)? Uważam, że Autor ma rację w polemice z M. Sitarzem (na s. 70, przyp. 105), acz polemiczna wypowiedź jest niekompletna (a co z interdyktem? - nie wiemy, czy Autor podziela opinię uznanych kanonistów, przykładowo: G. Bier, MK 1999, 415/3; K. Lüdicke, MK 1993, 1331/10, 1332/3).

Kolejna odsłona rozprawy nosi tytuł „Alienacja w prawie kanonicznym: formy, warunki i procedura”. W tym ważnym, bo wprost nawiązującym do tytułu książki, III rozdziale (s. 89142), docenić trzeba logiczny ciąg kolejnych kroków badawczych, analityczną dociekliwość Autora w wyciąganiu wniosków i żywo prowadzony tok narracji - wszystko to sprawia, że tę 
część rozprawy czyta się z zainteresowaniem. Uzyskujemy tu klarowne wyjaśnienie, dlaczego alienacja kościelnych dóbr doczesnych ma charakter wyjątkowy. Owszem, każde jej przeprowadzenie jest odstępstwem od zasady, że owe dobra, ściśle związane z misją Kościoła (niejako wyłączone z użytku doczesnego i poświęcone Bogu - T. Pawluk) nie powinny być zbywane. Właśnie dlatego czynności alienacyjne zaliczane są do aktów przekraczających granice zwykłego zarządu majątkiem kościelnym (kan. 1277 i kan. $1281 \$ 1$ ). Na wstępie Autor szerzej omawia alienację sensu largo (tu właściwsze było użycie polskiego odpowiednika, co pozwoliłoby uniknąć powtarzającego się błędu w tytule: jest sensu stricte, winno być sensu stricto; podobnie rzecz się ma z donaria votiwa - powinno być: donaria votiva) obejmującą czynności prawne regulowane polskim prawem cywilnym, takie jak ustanowienie dzierżawy, najmu, zastawu, hipoteki, służebności gruntowej i osobistej, użytkowania, udzielenia poręczenia, użyczenia, pożyczki oraz inne transakcje (w tym tzw. umowy nienazwane) - ich wspólnym mianownikiem jest okoliczność, że niosą z sobą ryzyko pogorszenia sytuacji majątkowej Kościoła. W tym kontekście ks. L. Świto - na kanwie regulacji kan. 1295 (o zachowaniu wymogów kan. 1291-1294 „przy podejmowaniu jakiejkolwiek transakcji, na skutek której majątek osoby prawnej może się znaleźć w gorszej sytuacji” - podkr. L. S.) - słusznie zwalcza pogląd, że „zaciągnięcie przez publiczną kościelną osobę prawną umowy pożyczki nie zabezpieczonej ograniczonym prawem rzeczowym nie może spowodować pogorszenia jej sytuacji majątkowej i co za tym idzie, nie jest czynnością alienacyjną sensu largo" (s. 92). Nie mniej ważnym ustaleniem Autora wydaje się konstatacja, że kodeksowe rozróżnienie: akty większej wagi (actus maioris momenti) - akty nadzwyczajne (actus extraordinariae administrationis) zarówno w doktrynie, jak i w pragmatyce postępowania podmiotów kościelnych nastręcza wiele trudności. Toteż niezrozumiała jest zwłoka w wypełnieniu przez Konferencję Episkopatu Polski dyspozycji kodeksowej zapisanej w kan. 1277, dotyczącej taksatywnego wskazania aktów nadzwyczajnego zarządzania (o czym była już mowa). Z przeprowadzonych przez Autora badań ankietowych, które objęły 27 polskich diecezji, można się natomiast dowiedzieć, że takie wskazania ogłosili biskupi 6 diecezji; godne uwagi są zwłaszcza szczegółowe uregulowania przedmiotowe w Diecezji Sosnowieckiej i Archidiecezji Krakowskiej (jeśli nie liczyć regulacji, które wkrótce wejdą w życie w Archidiecezji Warmińskiej). Przykładowy wykaz czynności przekraczających granicę i sposób zwyczajnego zarządzania, wydany przez Konferencję Episkopatu Włoch, kończy ten wątek analiz. Nie poznajemy niestety kryteriów, które kazały Autorowi posiłkować się tym właśnie przykładem. Wybrana forma tabeli - niezastosowana w prezentacji wspomnianych wskazań diecezjalnych - też budzi wątpliwości (czy nie należało - konsekwentnie - wybrać formę opisową i dołączyć pominięty /!/ komentarz, a tę i inne tabele zamieścić w Aneksie na końcu monografii?). Istotność analizowanej problematyki i mierzący się z nią wnikliwy dyskurs badawczy Autora dobrze pokazuje podrozdział poświęcony zakresowi podmiotowo-przedmiotowemu alienacji. 
Uwage przyciąga zwłaszcza autorska propozycja redefinicji kodeksowego pojęcia patrimonium stabile. O kwalifikacji: „majątek stały” nie powinien przesądzać sam charakter tego majątku, lecz zindywidualizowany probierz, na ile dany składnik majątkowy (przykładowo - obok nieruchomości - jakaś ruchomość czy gotówka) wpływa na stabilność sytuacji ekonomicznej konkretnego podmiotu kościelnego. Innymi słowy, o tym, czy powzięte wobec jakiegoś składnika majątkowego czynności należało uznać za alienację - bo wyczerpuje on znamiona patrimonium stabile - decydować winna każdorazowa ocena uwzględniająca rozmiar majątku danej osoby prawnej. Autor docieka też meritum ważności alienacji i przebiegu procedury alienacyjnej (słusznie koncentrując uwagę na wymogu uzyskania zgody kompetentnej władzy kościelnej), by uwieńczyć ten etap badań uznaniem zgody biskupa na alienację za akt administracyjny. Szkoda, że w tej wartościowej części monografii ks. L. Świto naraża się na zarzut nierzetelności i nieprofesjonalizmu. Otóż nie wiedzieć czemu, ważne ustalenia z okresu reformy KPK są serwowane czytelnikowi - bynajmniej nie wyjątkowo -,z drugiej ręki” (s. 105, 108, 127, 145).

Interesującemu IV rozdziałowi książki (s. 143-213) Autor przypisał wyrazisty, jasno sprecyzowany cel. Właśnie tu uzyskujemy odpowiedź na pytanie, jakie konsekwencje - w prawie Kościoła katolickiego i prawie polskim - niesie z sobą alienacja dokonana bez zachowania wymogów kanonicznych. Tak jak pierwszy podrozdział poświęcony jest przedstawieniu skutków wadliwej alienacji w świetle norm KPK (nota bene szkoda, że zaledwie na 7 stronach) - w przejrzystym układzie jednostek tematycznych: nieważność alienacji (z wykładnią kan. 1293, pomocniczo - kan. $1281 \$ 1,1291)$, odpowiedzialność majątkowa (kan. $1281 \$ 3$ ), odpowiedzialność karna (kan. 1377, 1328, $1315 \$ 3$ ) - tak trzy kolejne podrozdziały (63 strony tekstu) dotyczą uregulowań na gruncie państwowego porządku prawnego takich kwestii, jak: skuteczność wadliwej alienacji we współczesnej cywilistyce polskiej, cywilnoprawne skutki wadliwej alienacji oraz odpowiedzialność karna za wadliwą alienację. Śmiało można powiedzieć, że w tym wartościowym, bogatym merytorycznie rozdziale (wyróżniającym się w całej książce) Autor zrealizował wszystkie zamierzenia badawcze anonsowane we Wstępie. Czytelnik po pierwsze, zyskuje wgląd w proces dochodzenia do stabilnej „linii” orzecznictwa Sądu Najwyższego po 1989 roku, w sprawach dotyczących dokonania czynności alienacyjnych bez zgody kompetentnej władzy kościelnej; po wtóre, ma szansę zagłębić się w meandry dyskursu glosatorów (twórców glos do związanych z tematem wyroków tegoż Sądu), często diametralnie różniących się między sobą w argumentacji i konkluzjach; po trzecie, może śledzić - stanowczo i jasno artykułowane - odautorskie „Uwagi [...] do przedstawionych poglądów doktryny i orzecznictwa” oraz „Uwagi w przedmiocie nie objętym powyższym dyskursem”, by - w końcu - zapoznać się z cennymi propozycjami rozwiązania kwestii spornych, sformułowanymi przez Autora. Z jego ustaleń wynika, że Sąd Najwyższy od kilkunastu już lat konsekwentnie stoi na stanowisku, że normy prawa kanonicznego uzależniające skuteczność alienacji od zezwolenia wła- 
ściwego podmiotu władzy kościelnej mogą wpływać na skuteczność owej czynności prawnej w prawie polskim. Ważną w tym względzie uchwałę Sądu Najwyższego z 19 grudnia 2008 roku - a w niej pogląd, że alienacja dokonana przez kościelną osobę prawną bez wymaganego w prawie kanonicznym zezwolenia kompetentnej władzy Kościoła katolickiego jest czynnością prawną niezupełną - należy uznać za afirmację (i poniekąd przypieczętowanie) obowiązującej „linii” orzecznictwa. W świetle art. $103 \$ 1$ i 2 kodeksu cywilnego, w przypadku potwierdzenia umowy alienacyjnej przez właściwy podmiot władzy kościelnej, staje się ona umową niewadliwą i w pełni skuteczną. Natomiast w razie odmowy takiego potwierdzenia - umową bezwzględnie bezskuteczną; i tu ks. L. Świto opowiada się za stanowiskiem odmiennym, niż to, które głosi uchwała (o bezwzględnej nieważności umowy). Autor nie podziela też dalszej argumentacji składu sędziowskiego w niniejszej uchwale. O ile przesłanek uwzględniania przepisów prawa kanonicznego sędziowie Sądu Najwyższego upatrują w art. 4 i 19 konkordatu polskiego, o tyle starannie przeprowadzony wywód autorski podpowiada inną podstawę prawną, którą wyznaczają regulacje art. 35 i 38 kodeksu cywilnego oraz art. 5 konkordatu. Trafna w tym miejscu jest konkluzja, że „poddanie obrotu dobrami Kościoła kontroli władz kościelnych jest nie tylko ważną sprawą Kościoła, ale i emanacją jego autonomii i niezależności. W kontekście powyższego nie sposób zatem przyjąć, by zawarty w art. 5 konkordatu zapis dotyczący poszanowania swobody i autonomii Kościoła wyłączał poza jego nawias całą sferę związaną z kompetencjami władz kościelnych odnośnie nadzoru nad obrotem majątkiem kościelnym i by uznawał je za całkowicie irrelewantne na gruncie prawa polskiego" (s. 233).

Ostatni, V rozdział „Alienacja a fundusze europejskie” (s. 214-228) obejmuje trzy podrozdziały: „Kościół w Unii Europejskiej - aspekt finansowy”, „Wykorzystanie dotacji unijnych przez Kościół katolicki w Polsce” oraz „Umowa o eurodotację jako alienacja sensu largo w rozumieniu kan. 1295 KPK”. Jak wstępnie zauważa Autor, Unia Europejska stanowi wspólnotę światopoglądowo i religijnie neutralną, toteż nie może być mowy o bezpośrednim finansowaniu religijnej działalności Kościołów czy związków wyznaniowych. Wszelako jest rzeczą naturalną, że na takie wsparcie finansowe mogą one liczyć w związku z prowadzoną działalnością społeczną (zwłaszcza charytatywna), oświatowo-wychowawczą i kulturalną (w tym także restauracją zabytkowych obiektów). Kościół katolicki zatem, jak każda organizacja wyższej użyteczności publicznej, ma otwartą drogę do korzystania ze środków unijnych. Badania przeprowadzone przez ks. L. Świtę pokazują rosnące zainteresowanie podmiotów kościelnych w Polsce pozyskiwaniem takich środków. Widać to wyraźnie w latach 2007-2013, w których nasz kraj uzyskał z budżetu Unii Europejskiej (w ramach polityki spójności) ponad 67 mld euro. W tym okresie odnotowano dość znaczne aplikowanie Kościoła katolickiego o dotacje unijne - z jednej strony dla takich projektów, jak: remonty i zabezpieczenia budowli, odrestaurowanie zabytków czy rewitalizacji budynków kościelnych, z drugiej strony dla planowanych przedsięwzięć eduka- 
cyjnych, kulturalnych i społecznych (np. w zakresie pomocy społecznej, ochrony zdrowia itp.). Wskazując na regułę, że warunkiem zawarcia umowy o eurodotację jest dysponowanie minimalnym wkładem własnym (z reguły na poziomie 25\% wartości całego projektu), Autor słusznie podnosi kwestię ryzyka finansowego, którym - potencjalnie - obarczona jest realizacja projektów kościelnych: „Abstrahując od tego, że beneficjent, który nie jest jednostką sektora finansów publicznych, zobowiązany jest do ustanowienia zabezpieczenia umowy w formie wskazanej przez Instytucję Zarządzającą Regionalnym Programem Operacyjnym, to przystępując do realizacji projektu przyjmuje też na siebie bardzo szczegółowo określone obowiązki (wynikające m.in. ze sprawozdawczości, audytu, archiwizacji, informacji, promocji itd.), którym uchybienie może skutkować daleko idącą odpowiedzialnością. Należy powiedzieć, iż w przypadku stwierdzenia naruszenia obowiązujących procedur Instytucja Zarządzająca Regionalnym Programem Operacyjnym może domagać się zwrotu pobranego dofinansowania wraz z odsetkami w wysokości jak dla zaległości podatkowych” (s. 226). Niniejsze przesłanki upewniają o trafności konkluzji, że zawieranie tego rodzaju umowy wyczerpuje znamiona transakcji, o której mowa w kan. 1295 KPK (i istnieje obowiązek spełnienia wymogów, o których w kan. 1291-1294). Gdyby zatem umowa o eurodotację przekraczała kwoty summa minima i summa maxima, jej zawarcie winno podlegać kanonicznej procedurze alienacyjnej, co przede wszystkim wiąże się z koniecznością uzyskania zgody właściwego podmiotu władzy kościelnej. Autor słusznie argumentuje, że wypełnienie tego ostatniego warunku należałoby odnosić do planowanej umowy (zgoda na zawarcie umowy), a nie tylko do sposobu jej zabezpieczenia (zgoda na ustanowienie hipoteki, podpisanie weksla itp.). Ostatecznym zaś punktem odniesienia, czy zachodzi konieczność uzyskania zgody, winna być całkowita wartość projektu. Wszak chodzi o ryzyko nie tylko utraty środków własnych czy ustanowionego zabezpieczenia, ale również zapłaty odsetek w kwocie zależnej od wysokości dofinansowania.

W podsumowaniu merytorycznych walorów rozprawy wypada stwierdzić, że niewątpliwym osiągnięciem ks. L. Świty jest całościowe opracowanie zagadnienia alienacji majątku kościelnego w polskich realiach systemowo-prawnych - z dobrze zaplanowaną i poprawnie zrealizowaną metodologią badań. Rozwinięcie przy tym wielu kwestii szczegółowych stanowi o wkładzie Autora we współczesną debatę kanonistów i cywilistów w niełatwym obszarze spraw „mieszanych” (podlegających kompetencji zarówno władzy kościelnej, jak i władzy świeckiej). Książka niniejsza jest pierwszym w literaturze polskiej, kompleksowym studium poświęconym alienacji majątku kościelnego, i jako taka z pewnością nie pozostanie niezauważona w polskiej kanonistyce i cywilistyce, a z uwagi na swój wymiar praktyczny - wzbudzi zainteresowanie szerszego grona zarządców majątku kościelnego. 